\title{
The Effect of Price Perception, Brand Image and Personal Selling on the Repurchase Intention of Consumers B to B of Indonesian General Fishery Companies with Customer Satisfaction as Intervening Variables
}

\author{
Wenny Prihatini and Dendy Anggi Gumilang
}

\section{ABSTRACT}

\begin{abstract}
This study aims to analyze the effect of Price Perception, Brand Image and Personal Selling on Repurchase Intention of B to B Consumers in Indonesian Fisheries Public Companies (Perum) with Consumer Satisfaction as an Intervening Variable. The population in this study were 228 Perum Perindo consumers according to the company's internal data in 2019. The research sample who became respondents in this study was adjusted to 100 consumers. The analytical method used in this study is the Partial Least Square (PLS) analysis method. The results showed that (1) Price Perception has a significant influence on B2B Consumer Satisfaction, (2) Brand Image has a significant influence on B2B Consumer Satisfaction, (3) Personal Selling has a significant influence on B2B Consumer Satisfaction, (4) Consumer Satisfaction has an effect Significant on B2B Repurchase Intention, (5) Price Perception has a significant effect on Repurchase Intention with B2B Consumer Satisfaction as an intervening variable, (6) Brand Image has a significant effect on Repurchase Intention with B2B Consumer Satisfaction as an intervening variable, and (7) Personal Selling has a significant effect on Repurchase Intention with B2B Consumer Satisfaction as an intervening variable.
\end{abstract}

Keyword: Price Perception, Brand Image, Personal Selling, Consumer Satisfaction, Repurchase Intention.

\section{INTRODUCTION}

Indonesia has the advantage of being a maritime sector because of its enormous fishery resource potential. This potential causes Indonesian fishery products to have bright prospects so that good management is needed to achieve company goals [1].

The Indonesian General Fisheries Company (Perum Perindo) has been operating for 30 years so that it has become a trusted company for the management of marine products in Indonesia. Even so, the contribution of Perum Perindo to national income is still very small, so it indicates that the company must analyze the company's performance so that it has an impact on increasing the interest in repurchasing corporate consumers.

The contribution of Perum Perindo's operating income to the Gross Domestic Product (GDP) of the fisheries sector, although it has increased during the 2016-2018 period, is still very small. The contribution of Perum Perindo's business income when compared to the GDP of the fisheries sector was only $0.10 \%$ for the 2016 period, $0.27 \%$ in 2017 and $0.42 \%$ in 2018. The declining sales achievement in 2019 made the market share controlled by Perum Perindo decrease. This shows that the performance of Perum Perindo still needs to be improved to get a bigger market share.
Submitted : February 16, 2021
Published : March 25, 2021
ISSN: $2507-1076$
DOI: $10.24018 /$ ejbmr.2021.6.2.756
Wenny Prihatini*
Universitas Mercu Buana, Jakarta, Indonesia.
(e-mail: wenny20_02@yahoo.com)
Dendy Anggi Gumilang
Universitas Mercu Buana, Jakarta, Indonesia.
*Corresponding Author

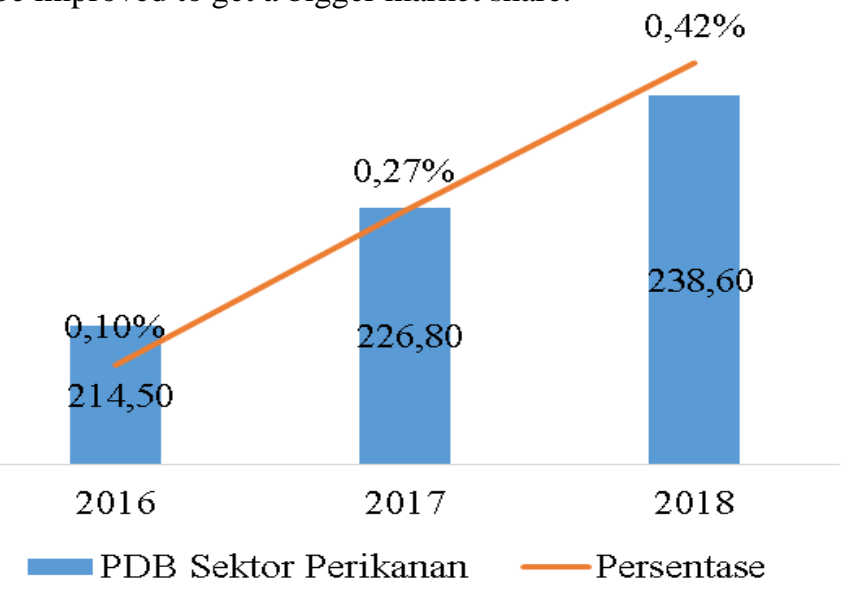

Fig. 1. Contribution of Perum Perikanan Indonesia to GDP.

As a comparison, Perum Perindo has several competing companies in the fishery product management segment including PT. Dua Putra Utama Makmur Tbk and PT Central Proteina Prima Tbk (CP Prima). The following is a comparison of the operating income of the three companies.

Perum Perindo has lower revenue than the three competing private companies, namely. The pre-survey results on $30 \mathrm{~B} 2 \mathrm{~B}$ respondents showed that customer satisfaction, price perception, brand image and personal selling were factors that 
played an important role in increasing repurchase intention.

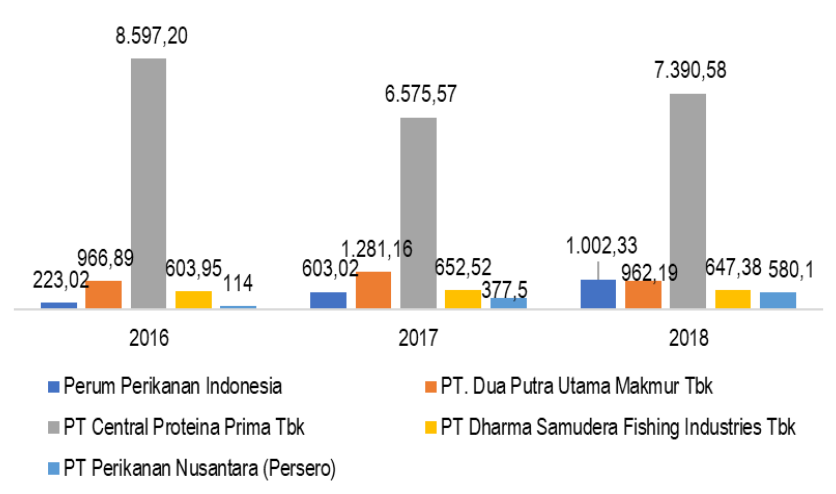

Fig. 2. Comparison of Revenue of Fisheries Companies in Indonesia (in billion Rupiah).

\section{LITERATURE REVIEW}

\section{A. Repurchase Intention}

Widjiono and Japrianto explain repurchase intention as an activity to make purchases more than once [2]. It arises as a consumer reaction after making a purchase and evaluating the performance of the company's products and services after making a purchase. Based on this description, it can be concluded that consumers repurchase intention is part of influencing consumers to buy or consume goods or services that are used regularly. The dimensions and indicators of repurchase intention are described by Kotler and Keller with 4 dimensions, namely transactional, referential, preferential, and explorative interests [3].

\section{B. Price Perception}

Price is defined as a unit that can be exchanged for products or services in order to obtain ownership rights to use the benefits of these products and services [4]. Price is a component of the marketing strategy set by the company with the aim of being added value for consumers in order to continue consuming the products and services being sold. Kotler and Armstrong explain 2 dimensions and indicators of price perception, namely consumer opinion regarding the price offered (attractiveness) and the fairness of the price offered (fairness) [5].

\section{Brand Image}

Brand is closely related to everything associated with a product or company. Brand is a combination of the name, motto, characteristics, and reputation of a product so that consumers can easily recognize and differentiate it from products from other sellers [6]. Rangkuti explained that recognition, reputation, and affinity are dimensions of brand image [7].

\section{Personal Selling}

Direct interaction between buyers and representatives of the company is needed to obtain accurate information about the products to be consumed or sold. Shimp argues that personal selling is the interaction of consumers and sellers where the process carried out is to influence consumers to buy the products offered [8]. Belch and Belch explain communication skills, product knowledge and empathy are dimensions of personal selling [9].

\section{E. Customer Satisfaction}

Satisfaction is the final result of the process of purchasing a product that is felt by consumers. Customer satisfaction is a very crucial factor in the success of a company. Setiawan et al explain satisfaction as consumer feelings as a result of comparing the performance of a product with consumer expectations or expectations [10]. Based on this, it is concluded that consumer satisfaction is the feeling of consumers when assessing factual conditions with expectations for the product or service. Zeithaml et al explain the dimensions of customer satisfaction, namely expectations, the delivery of products and services that are felt, confirmation or disconfirmation and complaining behavior [11].

\section{RESEARCH METHODOLOGY}

Based on existing theories and dimensions, the authors make a research framework.

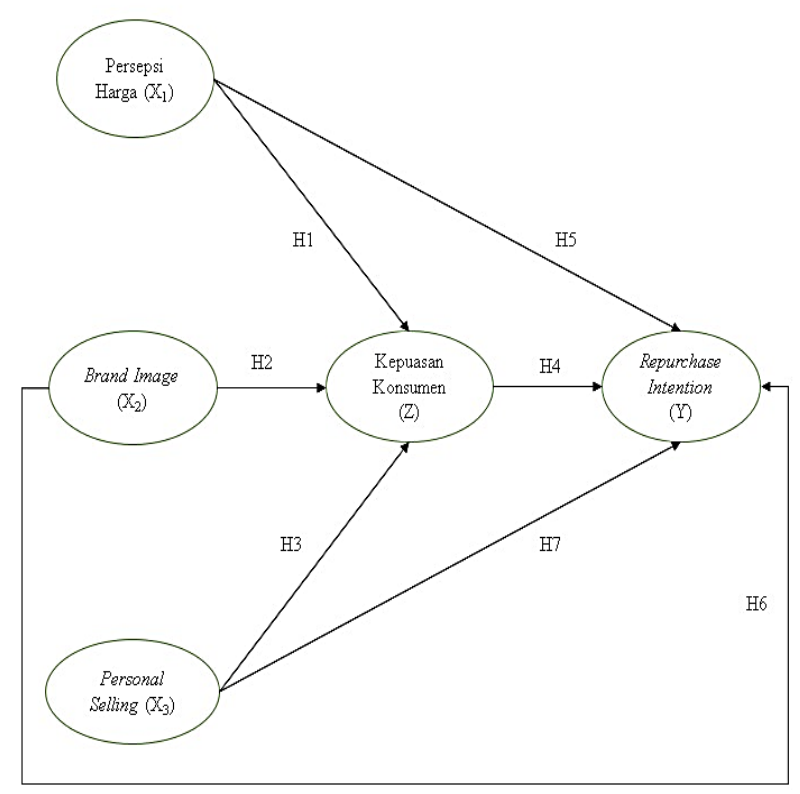

Fig. 3. Framework.

The quantitative approach was chosen through a questionnaire as a data collection instrument. The study population was B2B Perindo consumers as 228 according to internal data. While the number of samples refers to the technique of Hair et al where the total sample size was 90 respondents [12]. To analyze the research data, the Structural Equation Modeling (SEM) method was used which was processed using Smart PLS Version 3.0.

\section{RESULT}

\section{A. Characteristics of Respondents' Answers}

At this stage, an overview of the respondents' answers to the variables proposed and the indicators they have will be presented. In the statement of the repurchase intention variable, the lowest value concludes that B2B consumers still consider other things before deciding to continue buying products from Perindo.

In the perception variable, the lowest average value is 4.15 . This shows that B2B consumers still have the perception that 
the price set by Perindo is high. In the brand image variable, the lowest average value is 4.16 . This shows that B2B consumers have not been able to recognize Perindo products directly. In personal selling, the description of the respondent's answer with the interpretation of the salesperson owned by Perindo does not have good competence with the products being sold which produces the lowest value. Finally, at the lowest average value, the statement of customer satisfaction is that Perindo has not guaranteed on time delivery.

\section{B. Hypothesis Testing Result}

The results of hypothesis testing can be indicated by the $\mathrm{T}$ Statistic value where the recommended value must be above.

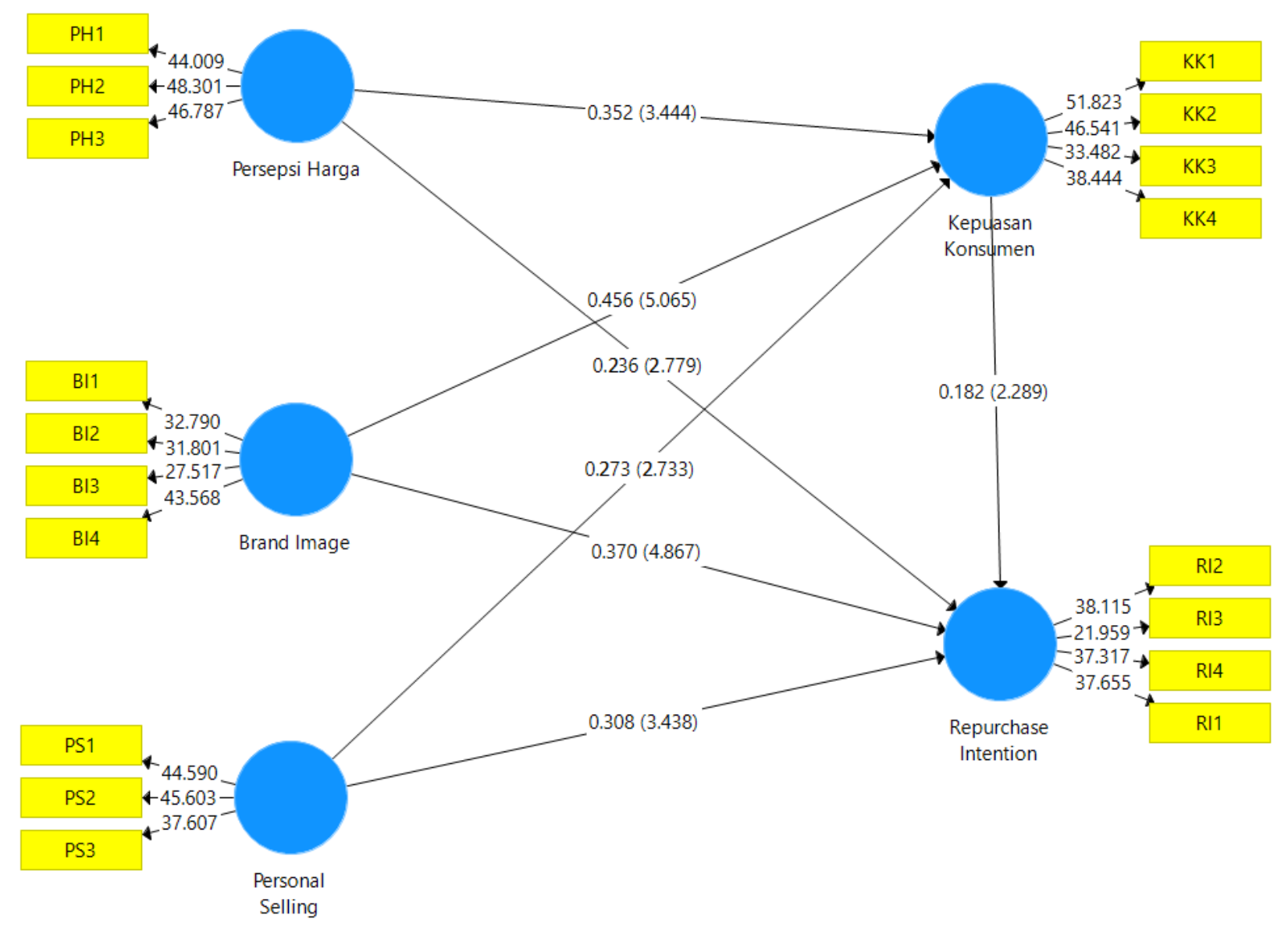

Fig. 4. Bootstrapping Results.

1) T-Statistic (bootsrapping) value test for direct effect has a value of 2.289 to 5.065 .

TABLE I: DIRECT INFLUENCE BETWEEN VARIABLES

\begin{tabular}{cccccc}
\hline & $\begin{array}{c}\text { Original } \\
\text { Sample } \\
(\mathrm{O})\end{array}$ & $\begin{array}{c}\text { Sample } \\
\text { Mean } \\
(\mathrm{M})\end{array}$ & $\begin{array}{c}\text { Standard } \\
\text { Deviation } \\
\text { (STDEV) }\end{array}$ & $\begin{array}{c}\mathrm{T} \\
\text { Statistics }\end{array}$ & $\begin{array}{c}\mathrm{P} \text { - } \\
\text { Values }\end{array}$ \\
\hline $\begin{array}{c}\text { Persepsi Harga } \rightarrow \\
\text { Kepuasan Konsumen } \\
\text { Btrand Image } \rightarrow\end{array}$ & 0.352 & 0.349 & 0.102 & 3.444 & 0.001 \\
$\begin{array}{c}\text { Kepuasan Konsumen } \\
\text { Personal Selling } \rightarrow\end{array}$ & 0.456 & 0.456 & 0.090 & 5.065 & 0.000 \\
$\begin{array}{c}\text { Kepuasan Konsumen } \\
\text { Kepuasan Konsumen } \\
\quad \text { Repurchase }\end{array}$ & 0.273 & 0.279 & 0.100 & 2.733 & 0.004 \\
\hline $\begin{array}{l}\text { Intention } \\
\text { Rention }\end{array}$ & 0.182 & 0.188 & 0.079 & 2.289 & 0.022 \\
\hline
\end{tabular}

a. $\mathrm{X}_{1}$ has an impact on increasing $\mathrm{Z}$ significantly. Basic conclusion because the original sample is 0.352 which is close to the +1 value and the T-Statistic is 3.444 (> 1.96).

b. $\mathrm{X}_{2}$ give the effect of increasing $\mathrm{Z}$ significantly. Basic conclusion because the original sample is 0.456 which is close to the +1 value and the T-Statistic is 5.056 (> 1.96).

c. $\mathrm{X}_{3}$ has an impact on increasing $\mathrm{Z}$ significantly. The basic conclusion is because the original sample is 0.273 which is close to the +1 value and the T-statistic is 2.733 (> 1.96).

d. Z has the effect of increasing Y significantly. The basis for the conclusion is because the original sample is 0.182 which is close to the +1 value and the T-statistic is 2.289 (> 1.96).

2) Shows the results of the T-Statistic (bootsrapping) value test, the indirect effect has a value of 2014 to 2.838 . Where 00 all relationships are accepted.

\begin{tabular}{|c|c|c|c|c|c|}
\hline & $\begin{array}{c}\text { Original } \\
\text { Sample } \\
\text { (O) }\end{array}$ & $\begin{array}{c}\text { Sample } \\
\text { Mean } \\
\text { (M) }\end{array}$ & $\begin{array}{l}\text { Standard } \\
\text { Deviation } \\
\text { (STDEV) }\end{array}$ & $\begin{array}{c}\mathrm{T} \\
\text { Statistics }\end{array}$ & $\begin{array}{c}\text { P- } \\
\text { Values }\end{array}$ \\
\hline $\begin{array}{l}\text { Persepsi Harga } \rightarrow \\
\text { Kepuasan Konsumen } \\
\rightarrow \text { Repurchase } \\
\quad \text { Intention }\end{array}$ & 0.164 & 0.165 & 0.035 & 2.838 & 0.000 \\
\hline $\begin{array}{l}\text { Btrand Image } \rightarrow \\
\text { Kepuasan Konsumen } \\
\rightarrow \text { Repurchase } \\
\quad \text { Intention }\end{array}$ & 0.283 & 0.285 & 0.041 & 2.014 & 0.045 \\
\hline $\begin{array}{c}\text { Personal Selling } \rightarrow \\
\text { Kepuasan Konsumen } \\
\rightarrow \text { Repurchase } \\
\quad \text { Intention }\end{array}$ & 0.231 & 0.233 & 0.025 & 2.273 & 0.024 \\
\hline
\end{tabular}


a. The indirect relationship between Price Perception (X1) on $\mathrm{Y}$ through $\mathrm{Z}$ has a positive and significant effect. This is indicated by the test results between the two variables which indicate the original sample value of 0.164 which is close to the +1 value and has a T-Statistic value of 2.838 (> 1.96).

b. The indirect relationship between Brand Image (X2) and $\mathrm{Y}$ through $\mathrm{Z}$ has a positive and significant effect. This is shown by the test results between the two variables which indicate the original sample value of 0.283 which is close to the +1 value and has a T-Statistic value of 2014 (> 1.96).

c. The indirect relationship between Personal Selling (X3) and $\mathrm{Y}$ through $\mathrm{Z}$ has a positive and significant effect. This is shown by the test results between the two variables which indicate the original sample value of 0.231 which is close to the +1 value and has a T-Statistic value of 2.273 (> 1.96).

3) Fornell Lacker Criterion Test

\begin{tabular}{cccccc}
\multicolumn{6}{c}{ TABLE III: FORNELL LACKER RESULT } \\
\hline & $\begin{array}{c}\text { Brand } \\
\text { Image }\end{array}$ & $\begin{array}{c}\text { Kepuasan } \\
\text { Konsumen }\end{array}$ & $\begin{array}{c}\text { Persepsi } \\
\text { Harga }\end{array}$ & $\begin{array}{c}\text { Personal } \\
\text { Selling }\end{array}$ & $\begin{array}{c}\text { Repurchase } \\
\text { Intention }\end{array}$ \\
\hline $\begin{array}{c}\text { Brand } \\
\text { Image }\end{array}$ & $\mathbf{0 . 9 7 8}$ & & & & \\
Kepuasan & 0.963 & $\mathbf{0 . 9 6 9}$ & & & \\
$\begin{array}{c}\text { Konsumen } \\
\text { Persepsi }\end{array}$ & 0.957 & 0.955 & $\mathbf{0 . 9 6 3}$ & & \\
$\begin{array}{c}\text { Harga } \\
\text { Personal } \\
\text { Selling }\end{array}$ & 0.933 & 0.944 & 0.952 & $\mathbf{0 . 9 6 0}$ & \\
$\begin{array}{c}\text { Repurchzse } \\
\text { Intention }\end{array}$ & 0.856 & 0.881 & 0.866 & 0.875 & $\mathbf{0 . 9 5 1}$ \\
\hline
\end{tabular}

In the table above, it can be seen that the correlation between similar variables is greater than the correlation between different variables. Therefore, the conditions for discriminant validity have been met

4) Reliability Test

\begin{tabular}{cccc} 
& TABLE IV: RELIABILITY RESULT & \\
\hline Konstruk & $\begin{array}{c}\text { Cronbach's } \\
\text { Aplha }\end{array}$ & $\begin{array}{c}\text { Composite } \\
\text { Reliability }\end{array}$ & Keterangan \\
\hline $\begin{array}{c}\text { Brand Image } \\
\text { Kepuasan }\end{array}$ & 0.895 & 0.927 & Reliabel \\
$\begin{array}{c}\text { Konsumen } \\
\text { Persepsi Harga } \\
\text { Personal }\end{array}$ & 0.921 & 0.944 & Reliabel \\
$\begin{array}{c}\text { Selling } \\
\text { Repurchase } \\
\text { Intention }\end{array}$ & 0.882 & 0.927 & Reliabel \\
\hline
\end{tabular}

From these results, it can be concluded that the construction has good reliability, or the questionnaire used as a tool in this research has been reliable or consistent.

5) R-Square $\left(R^{2}\right)$

\begin{tabular}{lcc}
\multicolumn{3}{c}{ TABLE V: R SQUARE RESULT } \\
\hline \multicolumn{1}{c}{ Konstruk } & R Square & R Square Adjusted \\
\hline Kepuasan Kepuasan $(\mathrm{Z})$ & 0.906 & 0.903 \\
Repurchase Intention $(\mathrm{Y})$ & 0.933 & 0.930 \\
\hline
\end{tabular}

Based on this test, it can be explained that X1, X2, and X3 have an influence contribution to customer trust $(\mathrm{Z})$ by 90.6\%. Meanwhile, X1, X2, X3 and Z have an influence on behavioral intention of $93.3 \%$.

\section{DISCUSSION}

\section{A. Effect of Price Perception on B2B Consumer Satisfaction}

Based on the research results, it is known that Price Perception has a significant effect on B2B Consumer Satisfaction. Price is defined as the value provided to consumers on the basis of the benefits that can be provided by a product or a service. Prices must reflect fairness in line with benefits and comparisons with prices prevailing in the market. Perindo must be able to set a reasonable price and not be far from competitors so that B2B consumers do not switch to using products from competitive companies and are satisfied with the performance of Perindo's products. Previous research stated that Price Perception has a significant effect on B2B Consumer Satisfaction [12].

\section{$B$. The Influence of Brand Image on B2B Consumer Satisfaction}

Based on the research results, it is known that Brand Image has a significant influence on B2B Consumer Satisfaction. Image is the overall impression or memory that consumers build and shape about a brand. In addition, image is defined as an individual's perception of a brand. In this study, it refers to the phenomenon of individual perceptions of Perindo. Previous research states that Brand Image has a significant influence on B2B Consumer Satisfaction [13].

\section{Effect of Personal Selling on B2B Consumer Satisfaction}

Based on the research results, it is known that personal selling has a significant influence on B2B consumer satisfaction. The benefits of the relationship are expected to generate more benefits for both parties. Perindo needs to pay attention to personal selling strategies in order to establish long-term relationships with consumers. Personal Selling is able to provide consumers with accurate information about the products and services provided by the company. Previous research stated that Personal Selling has a significant influence on B2B Consumer Satisfaction [14].

\section{The Effect of Customer Satisfaction on B2B Repurchase Intention}

Based on the research results, it is known that Customer Satisfaction has a significant effect on B2B Repurchase Intention. The satisfaction created by the company can occur if consumers feel the product received is in line with consumer expectations. When this can be done, consumer loyalty will be formed and increased to continue to make regular repeat purchases and even recommend the products they have purchased to colleagues and family. Strong customer satisfaction is an important factor that companies continue to look for so that the sustainability of the products sold can last a long time and be able to increase the company's reputation so that it has an impact on company profits. Satisfaction with service and product quality is what strengthens consumer behavior to make repeat purchases. this matter to Perindo. Previous research stated that Consumer Satisfaction has a significant effect on B2B Repurchase Intention [15]. 


\section{E. The Effect of Price Perception on Repurchase Intention} with B2B Customer Satisfaction as an Intervening Variable

The results showed that Price Perception has a significant effect on Repurchase Intention with B2B Consumer Satisfaction as an intervening variable. Price perception is the tendency of consumers to use price in providing an evaluation of the suitability of the benefits of a product which has a strong influence on purchase intention or satisfaction in the purchasing process. Evaluation of the price of a product benefit is said to be expensive, cheap, or moderate from each consumer, its evaluation of the price is not the same, because it depends on the opinion of the consumer himself. B2B consumers can re-purchase one brand and use it on an ongoing basis. Meanwhile, the satisfaction obtained by consumers can encourage repurchasing. By looking at a reasonable price, it will give a good impression to the company so that consumers are willing to make repurchase intention. Previous research stated that Price Perception has a significant effect on Repurchase Intention with B2B Consumer Satisfaction as an intervening variable [16].

\section{$F$. The Influence of Brand Image on Repurchase Intention with B2B Customer Satisfaction as an Intervening Variable}

The results showed that Brand Image had a significant effect on Repurchase Intention with B2B Consumer Satisfaction as an intervening variable. Image (Image) is a picture or concept about something. Thus, the image exists, but it is not real or cannot be described physically, because the image only exists in the mind. Brand Image is a representation of the overall perception of a brand and is formed from information and past experiences with that brand. The image of the brand is related to attitudes in the form of beliefs and preferences for a brand. Consumers who have a positive image of a brand are more likely to make purchases. Having good experience with a brand or company plus good experiences in the past will create customer satisfaction and become a reason for consumers to make repeated purchases. Previous research states that Brand Image has a significant effect on Repurchase Intention with B2B Consumer Satisfaction as an intervening variable.

\section{G. Effect of Personal Selling on Repurchase Intention with B2B Consumer Satisfaction as an Intervening Variable}

The results showed that Personal Selling had a significant effect on Repurchase Intention with B2B Consumer Satisfaction as an intervening variable. Personal Selling is a promotional strategy that is personal and allows long-term relationships with consumers. With personal selling, consumers will get information about the superiority of the products marketed by the company and then consumers will be interested in trying them and then decide to buy the products offered. Previous research stated that Personal Selling has a significant effect on Repurchase Intention with B2B Consumer Satisfaction as an intervening variable [17].

\section{CONCLUSIONS}

It is known that Price Perception, Brand Image, Personal Selling have a significant influence on B2B Consumer Satisfaction. Customer Satisfaction has a significant influence on B2B Repurchase Intention. Customer
Satisfaction is able to mediate the influence of Price Perception, Brand Image, Personal Selling on B2B Repurchase Intention.

For Perindo, it is hoped that it will be able to establish a more reasonable price policy for consumers, especially for consumers with a certain number of purchases as well as consumers who have been loyal to buy Perindo products. This will provide added value for consumers to continue buying products from Perindo and recommend them to colleagues to buy Perindo products.

For Perindo to be able to improve the competence of salespeople assigned by Perindo, especially in their knowledge of the products being sold. This will give $\mathrm{B} 2 \mathrm{~B}$ consumers' confidence to buy products from Perindo because they get clear information about the advantages of products owned by Perindo.

\section{REFERENCES}

[1] Ruslan E.I dan Maria P. (2013). "Pengelolaan dan Pengembangan Usaha Perikanan pada PT. Dwi Candra Mina Citra di Sidoarjo". Jurnal Agora, 1(3): 1-13.

[2] Widjono, L dan Edwin J. (2015). “Analisa Pengaruh Self Image Congruity Retail Service Quality dan Customer Perceived Service Quality terhadap Repurchase Intention dengan Customer Satisfaction sebagai Variabel Intervening di Broadway Barbershop Surabaya". Jurnal Manajemen Pemasaran, 9(1): 1-20.

[3] Kotler, P and Keller, L.K. (2016). Marketing Managemen, 15th Edition, Pearson Education, Inc.

[4] Tjiptono, F. (2016). Pemasaran Jasa (Prinsip, Penerapan, Penelitian). Yogyakarta: Andi.

[5] Kotler, P dan Armstrong. (2018). Principles of Marketing. Edisi 15. Global Edition. USA: Pearson.

[6] Sopiah dan Sangadji. (2016). Salesmanship (Kepenjualan). Jakarta: PT Bumi Aksara.

[7] Rangkuti, F. (2015). Riset Pemasaran. Jakarta: PT Gramedia Pustaka Utama.

[8] Shimp, A. Terence. (2014). Komunikasi Pemasaran Terpadu dalam periklanan dan Promosi. Jakarta: Salemba Empat.

[9] Belch, George E dan Michael A Belch. 2003. Advertising and Promotion, Integrated Marketing Perspective. United States: The MCGraw-Hill Companies.

[10] Setiawan, Margaretha F., Japarianto, E. (2016). “Analisa Pengaruh Food Quality dan Brand Image Terhadap Keputusan Pembelian Roti Kecik Toko Roti Ganep's di Kota Solo". Jurnal Manajemen Pemasaran, 1(1): 1-15.

[11] Zeithaml, V.A., M.J. Bitner, D.D. Gremler. (2013). Services Marketing: Integrating Customer Focus Across the Firm. 6th edition. Boston: Mc.Graw-Hill.

[12] Suhaily, L and Yasintha S. (2018). "How E-Service Quality, Experiential Marketing, and Price Perception to make Repurchase Intention on On-line Shopping". The International Journal of Business Management and Technology, 2(3): 10-23.

[13] Grace, P and Yee, S. (2020). "Rational or Emotional? An Examination of Customer Loyalty in B2B Packaged Food Retail Setting”. Asian Journal of Business Research, 10(1): 1-28.

[14] Byrnes, T and Bahaudin, G. (2008). "The Value of B2B Face-To-Face Sales Interaction in the United States, Canada And Latin America". International Business \& Economics Research Journal, 7(3), 79-90.

[15] Gil-Saura, I., Gloria, B., Maria E. (2018). "Satisfaction and Loyalty in B2B Relationship in The Freight Forwarding Industry: Adding Perceived Value and Service Quality into Equation". Transport Journal, 33(5): 1184-1195.

[16] Bellyanti, L.A., and Ketut R. (2019). "Role of Customer Satisfaction Mediated Relationship Between Service Quality and Price Fairness on Repurchase Intentions". International Journal of Sciences: Basic and Applied Research, 48(5): 48-59.

[17] Hoffman, M and Mayara, C.W. (2016). "Strengthen of B2B relationships by Using Personal Selling through Analyzing Sales Management in cultural consideration of Brazilian and Swedish IT companies". Dissertation in International Marketing, 1-90. 